\title{
Setting Social Status in Couples and in Partners' Budgetary Discretion in Central European Countries*
}

\author{
JIŘÍ VEČERNÍK and MARTINA MYSÍKOVÁ** \\ Institute of Sociology, Czech Academy of Sciences, Prague
}

\begin{abstract}
The conventional optics of social stratification research-in which the social position of the family unit is seen as being determined by the status of the male head of the household-have been challenged since the early 1970s. Similarly, economic research which views the household as a single unit has been questioned. Changing family circumstances and the increased share of couples in which the woman has higher earnings, education, and socioeconomic status mean that both these perspectives needs reformulating. The authors illustrate these issues using the European Union Statistics on Income and Living Conditions survey (EU-SILC) for five Central European countries (the Czech Republic, Hungary, Poland, Slovakia, and Austria) and draw on its 2006-2016 time series to present the characteristics of partners in couples and the relations between them. Female primacy has increased either in earnings, education, or socio-economic category in all countries except Hungary. The authors use the EU-SILC 2010 'Module on Intra-household Sharing of Resources' to test the hypothesis that a direct link exists between partners' social status split and separate welfare status, where female primacy in relevant characteristics is taken as a proxy for social status split, while separate welfare status is indicated by partners' budgetary discretion. The hypothesis is confirmed for Austria, the Czech Republic, and Slovakia, but not for Hungary and Poland. Apart from the personal factors of social status split, two family factors are strongly related to the probability of the budgetary discretion of couple partners across all countries: household income and marital status.
\end{abstract}

Keywords: social stratification, couples, status split, budgetary discretion, Central Europe

Sociologický časopis/Czech Sociological Review, 2019, Vol. 55, No. 6: 791-820

https://doi.org/10.13060/00380288.2020.55.6.492

\footnotetext{
* Acknowledgements: This work was supported by grant no. 18-09220S 'Social Stratification in the Czech Republic and Central Europe: 1968-2018' from the Czech Science Foundation. The EU-SILC datasets were made available on the basis of contract no. 265/2014-LFS-EU-SILC between the European Commission, Eurostat, and the Institute of Sociology, Czech Academy of Sciences. The authors would also like to thank the anonymous reviewers for their helpful and constructive comments, which substantially contributed to the overall readability of the final version of this paper. Responsibility for all the conclusions drawn from the data lies entirely with the authors.

** Direct all correspondence to: Jiří Večerník, Institute of Sociology, Czech Academy of Sciences, Prague, e-mail: jiri.vecernik@soc.cas.cz.
}

(C) Sociologický ústav AV ČR, v. v. i., Praha 2019 


\section{Introduction}

There are two streams of socio-economic research that partially overlap in their outcomes. One is sociological research on social stratification, in particular the branch that considers what the 'proper unit' of a social structure is, trying to shed light on family/individual social status. Social status is a latent variable, which cannot be directly measured [Oakes and Rossi 2003]. However, it can be reasonably approximated by various indicators. From the social stratification point of view, it has two different dimensions, which stem from Max Weber's classical formulation: at the family-household level, it is the relation to the consumption market, while at the personal level, it is mainly the relation to the labour market [Dale et al. 1985; Wright 1989 in Plutzer and Zipp 2001: 445]. In conventional stratification research, the male partner's position determines the social status of the family. Given the changes that have been taking place in recent decades affecting the position of women in the labour market, the family, and society, this approach no longer seems sustainable.

Although in stratification terms social homogeneity may prevail in some couples and, thus, the conventional approach based on the male partner's position may match the joint status of both partners, such an approach may not be appropriate for many other couples. Regarding Weber's concept of the individual level, social homogeneity/heterogeneity of couples in stratification terms can be described by the main characteristics of the partners that relate more or less to the labour market. While we suppose that there is a higher probability of joint social status among partners when both of them are either at the same level or if the man's position is higher than that of the woman (in accordance with the traditional concept), we assume that that there is a higher probability of a split in the partners' social status if the woman ranks higher in the relevant characteristics. ${ }^{1}$

The second stream is economic research and in particular the branch that questions the assumption of the equal distribution of welfare in families (in the sense of material well-being) and argues for the asymmetric distribution of resources among persons. Unlike social status, welfare status has a sound indicator that is commonly applied in economic research, which is income or wealth. However, the level of total household income does not necessarily determine the welfare status of individual family members. In traditional economic research, the household used to be the unit of observation and 'unitary household models' were applied. Developments in recent decades led many researchers to abandon this approach and the testing of the 'income pooling hypothesis' mostly led to its rejection in welfare economics [Chiappori 1992; Ward-Batts 2008]. Though there

1 The term 'status split' is understood here as the opposite of a joint, unified status that corresponds to the traditional organisation of the social structure along the lines of families/households. When applying this kind of innovative approach, we prefer to avoid such terms as 'divide' or 'separation', which instead suggest the break-up of a marriage. 
definitely are couples that pool all their income, this can no longer be considered the norm, and partners' separate welfare status must also be considered.

There is a link between the two-social and welfare-statuses that has not yet been pursued in current research. The relationship between them is close, but not straightforward. A person's position in the social status hierarchy does not directly determine personal earnings, which itself does not directly determine household income. Furthermore, household income does not necessarily translate into the welfare status of individual persons. However, in this article, we hypothesise that there might be a more direct link between partners' social status split and separated welfare status. The proxy for social status split is assumed to be female primacy in relevant characteristics (namely earnings, education, and/or occupational status), while separate welfare status is indicated by partners' budgetary discretion. More precisely, we expect female primacy, as a proxy for social status split, to be significantly related to partners' budgetary discretion, which is a proxy for separated welfare status. The aim of this article is to reveal whether such a link exists in five neighbouring Central European countries.

Four Central European transition (CET hereafter) countries were selected for analysis-the Czech Republic, Hungary, Poland, and Slovakia-and compared with Austria. All these countries have shared some common roots since the disintegration of the Austro-Hungarian Empire in 1918. ${ }^{2}$ Unlike the four CET countries, Austria managed to escape the colonial clutches of the Soviet Union through a treaty concluded in 1955 and was able to develop a successful market economy and democratic political system. It can thus serve as a benchmark for CET countries, which were only able to begin the same after 1989. The analysed region is rather traditional in terms of gender roles and related (in)equality [Křen 2019]. Proving at least partly the existence of separated personal social and welfare statuses and their mutual association in these countries would thus indicate that there is an ongoing process of diversion from traditional approaches. Such findings might help to fill the gap in the current stage of interdisciplinary research and also to a quantitative stratification analysis of gender inequalities, which have so far been neglected in East-Central Europe [Law and Sikora 2018].

This paper is organised as follows. The second section shows the two streams of socio-economic research as they are applied in the current literature. The third section presents the source of our data, the 'European Union Statistics on Income and Living Conditions' (EU-SILC hereafter), which have been collected since 2005, and its 2010 'Module on the Intra-household Sharing of Resources'.

\footnotetext{
${ }^{2}$ Before the First World War the Czech lands and Hungary were part of the Austro-Hungarian Empire as a whole, which included Slovakia as a part of Hungary, then called Upper Hungary. However, until 1918, Poland was partitioned between the Austro-Hungarian Empire, the Russian Empire, and the German Empire. By their religious roots, all the countries are predominantly and traditionally Catholic, except Hungary, which is mixed Catholic-Calvinist-Lutheran [see, e.g., Schwartz 2010].
} 
In the fourth section, the first part shows the changing composition of couples between 2006 and 2016, the second part describes partners' budgetary discretion in 2010, and the third part presents regression analyses of budget discretion using the characteristics of partners and their relations. The last section contains a discussion of the findings and the conclusion.

\section{Two research fields: social and welfare status}

There are two fields of investigation that exhibit some parallels but are factually unrelated in socio-economic research. One is the construction of social status in families. The other focuses on household welfare and the management of financial resources. While we are able to find some elements of internal household budget management that indicate the welfare status of household members, the construction of family members' social status is more puzzling. However, if social status differs within a family, we can assume that this is related to the partners' relative characteristics. Budget management in households can then be influenced by the partners' social status split. More concretely, discretionary spending by partners in a couple can arise from a possible social status split accompanied by the partial or even full financial independence of the female partner. Let's briefly review how the two streams of socio-economic research have been tackled in the literature.

In social stratification research, the established convention has been that the unit by which class/status composition is analysed is the family rather than the individual. However, the reference person whose position is taken as a proxy for the family's social status is an individual and almost always the male partner. In the past, the reference person was labelled the 'head of the household' and was usually the main breadwinner or the eldest householder, with males always taking precedence over females. The obvious reason was that, in the past, the man was the primary breadwinner, if not the sole person in the family connected to the labour market.

As early as the 1970s, Acker [1973] summarised, criticised, and rejected the assumptions of this conventional approach, which implicitly justifies the exclusion of sex as a significant variable in stratification research. She enumerated these assumptions as follows: (1) the family is the unit of the stratification system; (2) the social position of the family is determined by the status of the male head of the household; (3) females live in families, and therefore, their status is determined by that of the males to whom they are attached; (4) the female's status is equal to that of the male; (5) females determine their own social status only when they are not attached to a male; (6) females are unequal to males in many ways and are differentially evaluated on the basis of their sex, but this is irrelevant to the stratification system. ${ }^{3}$

\footnotetext{
${ }^{3}$ Independently and in the same year a similarly critical assessment of stratification research that is based only on the male population was also formulated by Haugh [1973].
} 
Acker referred also to the 'Marxist school' of social stratification, particularly to Wesołowski and Slomczynski [1968] in Poland and to Machonin [1970] in former Czechoslovakia. In the 1967 survey on social stratification headed by Machonin, male household heads were taken as units of observation, while households without male household heads were excluded from the survey. However, the same approach was applied in Western sociology, too. Goldthorpe [1983] insisted on adhering to the conventional practice, arguing that there was substantial similarity in the types of jobs held by husbands and their wives. To rebut critique of this approach, he argued-with Erikson - that the class identification and political leanings of employed married women are more closely associated with their spouse's class than with their own.

Erikson and Goldthorpe [1992] later modified this original position by adopting a 'dominance strategy', in which the class position of the household is taken to be that of the 'dominant' occupation in material terms-regardless of whether the occupation is held by the male or female partner. Much later, Blossfeld and Bucholz [2009] — referring to Blau and Duncan [1967] and Sewell and Hauser [1975] — again endorsed the view that status attainment research should regard the variation in the social position of male family heads as the key dependent variable. In contrast, Haller [1981] raised alternative hypotheses about stratification mechanisms regarding patterns of marital homogamy and the consequences of heterogamy. In an animated debate, 'a crisis in stratification theory' was declared [Mann 1986].

The conventional approach has become untenable given two streams of changes that have gained strength over time in advanced countries. The first involves general changes in the family sphere that have had important demographic consequences. Marriage is no longer a social status attribute, or at least it is much less important in this respect than it was in the past. There are growing numbers of adults who marry later or not at all, marriages are generally less stable, and there are more single-parent families and persons living alone, even as couples. The second and related area involves the growing economic independence of women in connection with their higher education, the much greater participation of women on the labour market, and women's increasing earnings [Blossfeld 1995; Blossfeld and Drobnič 2001; Esping-Andersen 2009; Oláh, Kotowska and Richter 2018].

Throughout these important changes, research has focused on two-earner families or dual-career couples. Blossfeld and Drobnič [2001] collected longitudinal studies on the shift from studies based on a male breadwinner to a dualearner model in 12 countries representing five different welfare regimes. They found a significant shift from the male breadwinner to the dual-earner model in all countries, but especially in transition countries (Hungary and Poland) and in the social-democratic societies of Scandinavia (Denmark and Sweden). However, as they found, the change in gender roles was asymmetric, with the greater movement of women into the traditional male sphere than vice versa.

Using EU-SILC data for 27 European countries, Klesment and Van Bavel [2015] examined the reversal of the gender gap in education and showed that ' ... 
hypogamy positively affects the probability that she earns more than half of the couple's income. Highly educated women are much ... more likely to be the main breadwinner than medium or low educated women, but this is particularly the case when their partners have medium or lower educational attainment'. Looking at the interaction with motherhood status, they found evidence that hypogamy is offsetting the motherhood penalty: college-educated women in a hypogamous union with school-aged children are as likely to be the main breadwinner as childless college graduates in a homogamous union' [ibid.: 27].

Both related streams of changes-in education level and in the relative earnings of women-raise the question of how to treat social class positions in dual-earner couples with respect to identifying the proper unit of analysis in stratification research. Blossfeld and Drobnič [2001] state that there is a growing stream of research suggesting that empirical studies should treat women just like men and that individuals and not families should be the units of analysis in inequality studies. They also remark that a major conceptual limitation of the individualistic approach to the study of social inequality seems to be their failure to acknowledge the degree to which the lives of men and women are linked via marriage and family relationships.

There is abundant debate regarding the necessary revision of the stratification concept. As Plutzer and Zipp [2001] summarise, critics of the conventional view offer two major alternatives. One is the sharing hypothesis, according to which the family's class position is a combination of the labour market positions of both spouses. The second is the individualistic hypothesis, according to which each spouse has his/her own status based on each one's occupation, without considering the position of the partner. However, the empirical analyses reported in the same paper do not resolve the controversy. A 'dynamic approach' is offered following Marshall, Roberts and Burgoyne [1996], where a variety of class experiences-class of origin, previous jobs, unemployment spells, etc.-are deemed to shape one's class attitudes and behaviour.

In welfare economics research, the sharing of resources within households has been studied since at least the 1980s. Instead of the 'unitary model', where the family is assumed to act as a single decision-making unit, alternative models were developed (for an overview, see Himmelweit et al. [2013]). 'Bargaining models' explain sharing outcomes according to the resource theory of power, which describes bargaining power as compensation for contributions to the household's welfare [Lundberg and Pollak 1996]. 'Collective models' share the assumption of a cooperative outcome, so that household resources are allocated in such a way as to make it impossible for one partner to be better off without worsening the situation of the other [Bourguignon and Chiappori 1992; Chiappori 1992].

Empirically, individual welfare in couples is not measured directly but rather is derived by surveying the financial satisfaction of family partners and consumption patterns or by analysing the decision-making processes and budgetary discretion of partners. 
Using the German Socio-economic Panel Study's data on financial satisfaction of family partners, Elsas [2016] analysed differences in financial satisfaction between household partners to examine welfare differences. The results clearly indicate that the equal sharing hypothesis must be rejected: sharing is not independent of the male income ratio, i.e. the distribution factor. Further, the results show that sharing is independent of the male income ratio only in couples where the woman is employed. Unequal sharing is asymmetric insofar as only one partner's entitlement to household income depends on the distribution factor. The partner who is perceived to contribute inadequately to the household income is the one whose welfare depends on the income ratio.

Using variables on the financial satisfaction of partners from the EU-SILC 2013 'Module on Well-Being', Mysíková [2019] found that men's preferences typically concur with the traditional male-breadwinner family model, as the male partner's financial satisfaction decreases as the female share of household income increases. Actually, in most countries analysed, men's satisfaction increases at the point where they are substantially out-earned by their wives, but this concerns only a small fraction of couples. Traditional preferences among women could be identified only in four out of 15 European countries, while otherwise a tendency towards 'egoistic' preferences favouring a larger personal share of household income predominates among women.

Using Hungarian panel data, Hajdu and Hajdu [2018] found a negative association between a woman's relative income and life satisfaction, not only for men but for women as well. They attribute this fact to the traditional male breadwinner mentality, which is, however, moderated by gender norms. Among those with less traditional gender attitudes, the woman's relative income is not associated with life satisfaction, whereas among those who favour traditional gender roles, the negative association is stronger. This finding is consistent with the interpretation that gender norms explain the negative coefficients. Respondents with traditional values feel distress and dissatisfaction when a woman's proportional contribution to household income increases and the man's breadwinning role is challenged.

As well as German and Hungarian surveys, Swiss and Italian panel surveys [Wise and Zangger 2017; Lucchini, Saraceno and Schizzerotto 2007; Carriero and Todesco 2018; Kulic, Minello and Zella 2018] were also used in empirical analyses of how household welfare is shared and the budgetary discretion of partners is set. In CET countries, there are suitable national surveys available for this kind of analysis, such as the Polish Panel Survey and the recent three-year Czech Household Panel Survey, but none of them has been used for this purpose to date. Regarding comparative data, one possible source is the Generations and Gender Programme that has been conducted since 2004 in selected countries [Gauthier et al. 2018]. Another source is the European Social Survey carried out on small samples [Vitali and Arpino 2016]. In addition to such general surveys, marriage registers are also used [Fraboni and Vitali 2019]. 
The most valuable comparative data source is the EU-SILC 'Module on the Intra-household Sharing of Resources' collected in 2010 in all EU (and some other) countries. Its basic results have been summarised by Nagy, Medgyesi and Lelkes in a study contracted by the European Commission [European Commission 2012a]. They found considerable heterogeneity in the relevant patterns across EU countries, and this also concerns the countries we are interested in, which are dispersed along relevant indicators. For instance, the proportion of couples treating income as a shared resource differs between Slovakia (at about $60 \%$ ) and even somewhat less in Austria) and Hungary (at about 80\%), with the Czech Republic and Poland located in the middle (at about 70\%). Decision-making about the family budget in general is balanced most among couples in the Czech Republic and Hungary (94\%) and less in Slovakia and Poland (72\%) and Austria (67\%).

Using the same data source, Maksymovich [2017] showed how much decision-making is shared in households with respect to various family budget items. He found that equally shared decision-making in a household is closely connected to better household living conditions. Second, while predominant decision control accrued to either partner correlates with worse living conditions, this is more pronounced for women than for men. Finally, the distribution of the mode of decision-making in households does not strongly predict the regime of family finances.

\section{Data source, the variables and methodology}

Our data source is the EU-SILC statistical survey, designed and technically supervised by Eurostat, and fielded in European countries since 2005. By using the main sections of this survey that are fielded annually, we can observe the trends in the relative educational, occupational, and earnings characteristics of persons living in households (see Table 1 on dual-earner couples below). Unlike the view 'from the outside' provided by key characteristics of partners in couples, we can also look at households to some extent 'from the inside' by using the EU-SILC 2010 'Module on the Intra-household Sharing of Resources' (hereinafter just 'the Module') to analyse household budget management as declared by the partners in a couple. ${ }^{4}$

The Module sample contains households with at least two persons aged 16 and over. Some of the questions only targeted adults living with a partner. At the household level, the respondent responsible for the household questionnaire was asked a few questions about the regime and management of household finances. At the individual level, each current household member aged 16 and over were

\footnotetext{
4 To observe the trends in the composition of couples and relationships within them, the samples are constructed from EU-SILC data of 2006, 2010, and 2016 (EU-SILC Cross UDB, the version from October 2017).
} 
asked questions that related to their participation in managing the household budget and decisions concerning consumption and savings/debt. All the target variables related to the current situation in the reference period [European Commission 2012a].

One question asked on the personal level inquiring into the discretion of each partner regarding household resource management is particularly important for our analysis: 'Proportion of personal income kept separate from the common household budget' (see Table 2). In order to deal with the problem of the small number of answers in some categories,, the answers were used as dependent variables in our analyses after they were recoded as follows: 1 - none, 2 - less than half of personal income, 3 - about half of all personal income or more. In Tables 3 and 4 below, ordered logistic regression is applied, with marginal effects, for outcomes (1) and (3), instead of the regression coefficients presented. The dependent variable ranks from 'pooling all income' to 'keeping income separate'. Positive marginal effects for outcome (3) will thus indicate a greater tendency towards budgetary discretion.

The models in the section below with the analysis of partners' budgetary discretion are analysed separately for male and female partners. The reason is that the partners do not necessarily contribute equal portions of their personal income to the family budget. For instance, a contribution of the same absolute amount from the incomes of both partners might be the preferred scheme in some families, but it could lead to different proportional contributions. As the figures in the bottom row of Table 2 below suggest, the share of partners who contribute a different proportion of their income to the family budget (based on their own individual assessment) ranges from $6 \%$ (Hungary) to $38 \%$ (Austria). ${ }^{5}$

Explanatory variables are represented by various personal and couple characteristics. Earnings, which could be assumed to be one of the most important factors influencing decision-making and budgetary discretion, are included in relative terms and in the form of total couples' earnings. Similarly, other personal characteristics that might perform as potentially decisive factors-education, socio-economic status, and age-are included in relative and absolute terms. While our main interest is in the gap between partners, female characteristics serve as an anchor to capture the absolute position of the couple. The joint characteristics of couples include marriage, length of cohabitation, and the number of children. ${ }^{6}$

\footnotetext{
${ }^{5}$ However, as a robustness check, we also ran models where only samples of partners reporting the same answers were applied. Given that no substantial differences were found between the two procedures, the results of the second one are not presented here. ${ }^{6}$ For instance, we can assume that marriage is related to greater trust between the partners, who share more of their personal earnings and simultaneously allow each other more freedom to make personal expenditure decisions. This corresponds to the results formulated on the basis of Canadian and Czech data, indicating that cohabiting couples are more likely to keep their income completely separate [Hamplová et al. 2014].
} 
To be more specific about the explanatory variables analysed, relative monthly earnings are defined as the share of female-earned income relative to the sum of earned income of both partners. Since the income variables refer to the previous calendar year in the EU-SILC, monthly earnings are determined according to the number of months worked, with part-time work carrying half the weight. Earnings include income from employment and self-employment. Relative earnings are a continuous variable. Moreover, in order to avoid extremes, relative earnings are used to define the sample of dual-earner couples by limiting the female share of earnings to the interval of 5-95\%. Total couple earnings (equivalised by the OECD modified scale) are divided into quintiles, and therefore four dummies are used in the analysis-quintiles 2 to 5 .

Education is described by a dummy for female tertiary education (ISCED 5-6) and the educational gap between partners by two dummies for the male or the female partner having a higher level of education (differentiated as ISCED levels $0-1,2,3,4$, or 5-6). Socio-economic, or occupational, status (categorised according to the European Socio-economic Classification schema or ESeC into nine categories) is expressed as a dummy for female ESeC $1-2$, and two dummies for the relative status of partners that describe either the male or female higher category (by $2+$ points). ${ }^{7}$

The ESeC categories define different positions in the labour market, distinguishing first between employers, the self-employed, employees, and persons involuntarily excluded from the labour market (who never worked or are unemployed), and second between employees on the basis of their employment relations and conditions, as employees occupy different labour market and work situations. As Harrison and Rose [2006: 6] stress, '[s]ince the schema is designed to capture qualitative differences in employment relationships, the classes are not consistently ordered according to some inherent hierarchical principle'. The main problem is with ranking employed and self-employment occupations. Since the distance of just one category could be misleading, we apply the distance of two and more categories. In any case, the socio-economic status indicated is only approximate.

Age is included as a dummy for young women (aged 25-34) and age gaps are represented by two dummies, one for men who are older by $6+$ years and one for men who are younger. Regarding the characteristics of couples, a dummy for marriage has to be controlled for, aas a de jure partnership, or marriage, is more often accompanied by income pooling than a de facto partnership, i.e. cohabitation. The number of dependent children in the household is assumed to control for different financial priorities and a higher level of commitment to the partnership.

7 The ESeC variable is not directly included in EU-SILC datasets but it could be constructed with the help of available variables, using tools provided by GESIS (https://www.gesis. org/en/gml/european-microdata/EU-silc/). Unfortunately, the more detailed classification offered by the International Socio-Economic Index of Occupational Status (ISEI) cannot be constructed on the base of the EU-SILC survey. 
In addition to the analyses presented below in Tables 3 and 4, we also examined the effect of cumulated female primacy in education, socio-economic categories, and earnings, presented in the bottom rows of Table 1. Optimally, triple interaction terms (relative education*relative socio-economic category*relative earnings) should be added in the regression models among explanatory variables; however, this cannot be done because the percentage of couples in which the woman has primacy in all three characteristics is negligible. Therefore, we tested the pairwise interactions terms and found that only the interaction of relative earnings and education returns a reasonable result: the share of couples in which the woman has primacy in these two characteristics counts for at least $5 \%$. The interaction term was found to border on the $10 \%$ level of significance in only a few cases but was otherwise insignificant. Therefore, the interaction terms of the relative characteristics were not added to our regressions.

The samples for analysis were limited to couples among persons aged 2554 years, in which the only other household members are dependent children. Households with other adult members are excluded to avoid a possible bias stemming from more complicated sharing rules and a within-family division of tasks. Further, only dual-earner couples are included, i.e. couples in which both partners contribute at least $5 \%$ of the family budget. To observe trends in the composition of couples and the relationships within them, the samples are constructed using EU-SILC data from 2006, 2010, and 2016. The main regression analyses are based on the 2010 survey, including the Module's variables. The descriptive statistics for the explanatory variables are presented in the Appendix (Table A3).

Here we must point out some limitations to the data. The main problem relates to the use of proxy interviews, in which one partner provides answers for the other partner, who was unavailable. Proxy answers are allowed in the EU-SILC in general, but not all countries accepted them for the Module. There are no proxy answers for Austria or Poland, and as a result a large share of values in our sample of couples are missing from the data from these countries: about $15 \%$ of male and $30 \%$ of female answers about budgetary discretion are missing for Austria and vice versa for Poland. Regarding the characteristics we are interested in, female primacy in earnings, education, and socio-economic status, there is no statistically significant difference between the groups with a missing and an answered dependent variable, with three exceptions. In Austria, female primacy in education is less frequent (by 6 percentage points) within the excluded group of male partners with missing values, while female primacy in socio-economic status is more frequent (by 8 percentage points) within the excluded group of female partners with missing values. In Poland, female educational primacy occurs less often (by 10 percentage points) within the excluded group of female partners with missing values.

In the remaining three countries, proxy answers are more common among men than women, which means that women answer on behalf of their male partners more often than vice versa. While proxy answers are somewhat rare in Slovakia (roughly $3.5 \%$ for men and 1\% for women), they range from $8 \%$ for women to 
$29 \%$ for men in Hungary. Proxy answers may reflect the subject's own assessment rather than the view of the partner, and this may result in identical answers being recorded for both partners. While there is a tendency towards a greater share of 'same answers' being observed in couples where one partner proxied the second one's answer, this is not a general rule and the share of 'same answers' is usually roughly two percentage points higher than for couples where both partners answered personally. Still, less apparent deviations in the proxy answers may exist, as the couples with proxy answers may systematically differ from those in which both partners responded personally. For these reasons, in the Appendix we provide models in which the proxy answers are excluded from the sample to check for robustness (Tables A1 and A2) and comment on the results where relevant.

\section{Couples' dynamics and partners' budgetary discretion}

\section{A description of the composition of couples}

EU-SILC datasets covering the period of 2006-2016 enable us to follow changes in family composition and the relative characteristics of couples. The points of reference are 2006 (the second year of the EU-SILC surveys, when data collection was already well established), 2010 (the year of our special interest because the Module was available), and 2016 (currently the last available year for all countries involved). Taking dual-earner couples within the specified age limit (25-54), we can refer to the homogeneity of couples in terms of earnings, education, and socio-economic category and changes to them over the past decade. A related question concerns a possible rapprochement of countries within the Central European region.

As Table 1 shows, differences across countries regarding the share of dual-earner couples in the given age range have decreased in the past ten years and ranged between $74 \%$ in Poland and 79\% in Slovakia in 2016. In all countries, a steady increase in dual-earner couples has occurred. The reverse side of this trend is a decreasing percentage of couples with dependent children. Another clear trend is the increasing percentage of cohabiting (not married) couples, which doubled in the Czech Republic and Austria and roughly tripled in Poland and Slovakia. An increasing percentage of couples with women who are better educated than men has been also a consistent trend and was observed in all the countries except Hungary.

For the other characteristics of couples, minor fluctuations are found more than consistent trends. While average relative earnings (the ratio of the woman's earnings to the couple's total earnings) is quite stable in all countries and not very dissimilar, the percentage of women out-earning men differs considerably. This percentage shows a significant decreasing trend only in Hungary; however, that is where the largest share of couples close to earnings equity is found: $30 \%$ to $40 \%$ of couples in Hungary have relative earnings between $45 \%$ and $55 \%$ (not pre- 
sented in Table 1), making this measure highly volatile. ${ }^{8}$ In the other countries, the trend is unclear or weak. Also, changes in the structure of couples' socioeconomic status differ across countries even more than in the case of out-earning. The structure of socio-economic status changed significantly in Hungary and Poland, mostly with men losing primacy.

We assume that there is a higher probability of social status split among couples with female primacy in some of the dimensions we are measuring here. Looking at the relevant rows in the 2016 section of Table 1, in the case of earnings the percentage of such couples was above $20 \%$, ranging between $22 \%$ in the Czech Republic and 30\% in Poland. In the case of education the percentage of couples with female primacy in 2016 was about $20 \%$ in the observed countries, ranging between $15 \%$ in the Czech Republic and $28 \%$ in Poland. In the socio-economic category, the percentage of such couples was below $20 \%$, ranging between $13 \%$ in Hungary and $19 \%$ in Poland.

Considering all three key characteristics of social status split, female primacy appears in one of them in about $40 \%$ of couples, ranging in 2016 between $35 \%$ in Hungary and $42 \%$ in Poland. The reason for such a large percentage is that the female primacy in these three characteristics overlap only slightly: in particular, a person's socio-economic category often does not overlap with education. Once we consider female primacy in two of the characteristics at the same time, the share of such couples is much lower: roughly $12 \%$, ranging between about 9\% in the Czech Republic and Slovakia and almost $14 \%$ in Poland and Austria. We assume that-noting the negligible percentage $(1 \%)$ of couples with female primacy in all three aspects-couples with female primacy in at least one of the aspect represent a 'space' for a possible social status split between partners.

Regarding the share of couples in which women out-earn men, there is one caveat that needs mentioning. We suspect that the percentage of these couples indicated in particular in the Hungarian and Polish data is overvalued as a result of the possible underestimation of total male earnings. This has to do with secondary jobs that are likely not to have been declared fully in the survey, or with other additional pay likely not declared at all. In both countries, secondary jobs and private activities were allowed under the communist regime. As Sik [1992, 2009] noted, the second economy of state socialism to some extent became the informal economy of transition, and the Kadarist experiment in Hungary (allowing small craftsmen and traders) was very advantageous in this sense. According to Gardes and Starzec [2009], who analysed the extensive secondary sector in Poland (especially in farming, which was never fully privatised), 'the rural population appears as the main actor in informal markets' [ibid.: 56]. Unlike those two countries, the tough regime in former Czechoslovakia allowed secondary (economic) activities only to a negligible degree [Večerník 2011].

\footnotetext{
${ }^{8}$ Therefore, a continuous relative earnings variable is applied in the regression models in the section on partners' budgetary discretion.
} 
Table 1. Characteristics of dual-earner couples in 2006-2016 (\%)—first part

\begin{tabular}{|c|c|c|c|c|c|}
\hline & $\mathrm{CZ}$ & $\mathrm{HU}$ & PL & SK & AT \\
\hline 2006-Percentage of all couples & 69.2 & 67.0 & 62.6 & 76.6 & 70.5 \\
\hline Relative earnings (RE) (mean) & 40.8 & 44.9 & 44.5 & 43.3 & 41.4 \\
\hline Woman higher earnings: RE $>50 \%$ & 20.6 & 34.5 & 33.5 & 26.2 & 24.6 \\
\hline Man higher level of education & 12.4 & 13.8 & 8.3 & 10.4 & 25.8 \\
\hline Same level of education & 77.6 & 64.9 & 66.8 & 78.2 & 55.6 \\
\hline Woman higher level of education & 10.0 & 21.3 & 24.8 & 11.4 & 18.6 \\
\hline Man higher ESeC by 2+ & 30.2 & 33.3 & 34.0 & 36.9 & 22.4 \\
\hline Similar ESeC & 50.0 & 49.6 & 54.4 & 46.4 & 56.8 \\
\hline Woman higher ESeC by $2+$ & 19.9 & 17.1 & 11.6 & 16.7 & 20.9 \\
\hline Woman's primacy in 1item & 36.6 & 42.3 & 41.0 & 38.9 & 39.4 \\
\hline Woman's primacy in 2 items & 6.9 & 14.6 & 13.7 & 7.5 & 10.7 \\
\hline Woman's primacy in 3 items & - & 0.5 & 0.3 & 0.1 & 0.7 \\
\hline With dependent children (0-24) & 74.9 & 78.4 & 82.1 & 88.8 & 67.1 \\
\hline Not married & 11.7 & 17.1 & 8.7 & 4.1 & 14.5 \\
\hline 2010_Percentage of all couples & 71.0 & 68.9 & 70.0 & 78.1 & 73.3 \\
\hline Relative earnings (RE) (mean) & 40.5 & 44.9 & 44.3 & 42.5 & 42.3 \\
\hline Woman higher earnings: RE $>50 \%$ & 18.9 & 32.6 & 32.9 & 21.4 & 30.8 \\
\hline Man higher level of education & 12.1 & 11.6 & 7.4 & 11.1 & 28.8 \\
\hline Same level of education & 75.4 & 66.3 & 67.6 & 73.7 & 51.1 \\
\hline Woman higher level of education & 12.5 & 22.1 & 25.0 & 15.2 & 20.2 \\
\hline Man higher ESeC by $2+$ & 29.5 & 33.4 & 33.9 & 33.9 & 25.6 \\
\hline Similar ESeC & 50.7 & 49.2 & 49.9 & 48.6 & 51.5 \\
\hline Woman higher ESeC by $2+$ & 19.7 & 17.4 & 16.1 & 17.5 & 22.9 \\
\hline Woman's primacy in 1 item & 37.3 & 38.2 & 42.8 & 37.5 & 45.1 \\
\hline Woman's primacy in 2 items & 6.4 & 15.8 & 15.1 & 8.0 & 12.8 \\
\hline Woman's primacy in 3 items & 0.2 & 0.8 & 0.3 & 0.1 & 1.0 \\
\hline With dependent children (0-24) & 76.7 & 78.0 & 78.6 & 82.5 & 67.1 \\
\hline Not married & 16.8 & 17.3 & 14.9 & 7.3 & 23.4 \\
\hline
\end{tabular}


Table 1. Characteristics of dual-earner couples in 2006-2016 (\%)—second part

\begin{tabular}{lccccc}
\hline & CZ & HU & PL & SK & AT \\
\hline 2016-Percentage of all couples & 75.4 & 77.7 & 74.2 & 78.6 & 76.8 \\
Relative earnings (RE) (mean) & 41.0 & 45.4 & 44.2 & 43.8 & 41.4 \\
Woman higher earnings: RE > 50\% & 21.5 & $28.6^{*}$ & 30.2 & $23.5^{*}$ & $27.3^{*}$ \\
Man higher level of education & $10.0^{*}$ & 12.2 & $7.9^{*}$ & $7.7^{*}$ & $22.5^{*}$ \\
Same level of education & $74.9^{*}$ & 66.4 & $64.4^{*}$ & $73.4^{*}$ & $56.7^{*}$ \\
Woman higher level of education & $15.1^{*}$ & 21.4 & $27.7^{*}$ & $18.8^{*}$ & $20.9^{*}$ \\
Man higher ESeC by 2+ & 29.1 & $30.2^{*}$ & $27.8^{*}$ & 30.2 & 22.8 \\
Similar ESeC & 52.4 & $57.0^{*}$ & $57.4^{*}$ & 52.1 & 57.8 \\
Woman higher ESeC by 2+ & 18.6 & $12.8^{*}$ & $14.8^{*}$ & 17.6 & 19.4 \\
Woman's primacy in 1 item & 37.6 & 34.9 & 42.4 & 39.9 & 37.6 \\
Woman's primacy in 2 items & 8.8 & 12.4 & 13.8 & 9.7 & 13.4 \\
Woman's primacy in 3 items & 0.1 & 0.8 & 0.7 & 0.4 & 1.2 \\
With dependent children $(0-24)$ & $72.8^{*}$ & $70.9^{*}$ & $75.0^{*}$ & $82.1^{*}$ & $64.0^{*}$ \\
Not married & $24.4^{*}$ & $21.5^{*}$ & $23.6^{*}$ & $13.4^{*}$ & $28.9^{*}$ \\
\hline
\end{tabular}

Source: EU-SILC 2006, 2010, 2016 (EU-SILC Cross UDB-version of October 2017). Authors' computations.

Note: Weighted by national cross-sectional weights. The percentage of all couples represents the share of dual-earner couples to dual- and single-earner couples aged 25-54 with no other adult household members. Woman's primacy in 1-3 items expresses the share of couples where the woman ranks higher than the man in one to three of the following characteristics: earnings, education and socio-occupational status. ${ }^{*} \mathrm{Chi}$-square test of association showed a statistically significant (at the 5\% level) relationship between a characteristic (the continuous relative earnings not considered) and the time of the survey (this is indicated with asterisks in the bottom part of the table for the year 2016 only). 
In fact, no exact figures, and especially comparative figures, regarding secondary earnings and their disparities by gender are available. The EU-SILC datasets are not very helpful in this area, as the unwillingness of respondents to report informal activities means we need to question their reliability. The survey includes information only on the hours spent in a secondary job, which differ across countries. In 2016, the percentage of workers who claimed to work at least one hour on a secondary job was 2-3\% in the Czech Republic, Slovakia, and Hungary (probably heavily undervalued, especially for Hungary), 9\% in Poland, and (more credibly) 6\% in Austria. In all the reported figures, men dominate.

\section{A description of the budgetary discretion of partners}

Unlike the picture provided by the personal and relative characteristics of partners in couples, which is a view somewhat 'from the outside', we can also look at couples somewhat 'from the inside' using the information about partners' discretion in household budget management that is provided by the EU-SILC 2010 'Module on Intra-household Sharing of Resources'. In our concept, this provides us with a look at the partners' individual welfare status, in contrast to the picture painted by their social status characteristics. Our aim is to find any clues about whether a difference in social status, in this case female primacy, is related to a separate welfare status, namely if partners keep their income separate.

The Module question we are interested in is about the proportion of personal income kept separate from the common household budget (Table 2). The answers range from the option 'all my personal income' to 'none'. If we merge the first three options into one category (half or more of all personal income is kept separate), we find that the greatest share of people who keep money separate for personal use is found in Austria and the Czech Republic (29\% and 21\% by the male partner, $31 \%$ and $22 \%$ by the female partner, respectively), while the greatest pooling of incomes is seen in Hungary (79\% of male partners and $81 \%$ of female partners keep no money separate for personal use) and Poland (72\% of males and females keep nothing separate).

We should be cautious in interpreting the figures on Poland, as there is a massive number of missing values in this country sample, in particular among the responses provided by men: values are missing for 31\% of men and $9 \%$ of women. Austria is also missing a large number of values: $17 \%$ of men and $20 \%$ of women. The large share of missing values is caused by proxy answers not being allowed in these two countries, as noted above.

\section{Analysis of the budgetary discretion of partners}

The budgetary discretion of partners in couples can be explained in relation to levels of education, socio-economic category, earnings, and the age of the part- 
Table 2. Proportion of personal income kept separate from the common household budget in $2010(\%)$

\begin{tabular}{lrrrrr}
\hline & CZ & HU & PL & SK & AT \\
\hline Male partners: & & & & & \\
All my personal income (3) & 4.9 & 0.8 & 6.2 & 3.1 & 0.4 \\
More than half of my personal income (3) & 8.1 & 2.3 & 3.5 & 5.2 & 12.3 \\
About half of my personal income (3) & 8.0 & 1.6 & 2.9 & 4.5 & 16.3 \\
Less than half of my personal income (2) & 13.3 & 16.1 & 15.7 & 48.7 & 31.0 \\
None (1) & 65.7 & 79.2 & 71.7 & 38.4 & 39.9 \\
Total & 100.0 & 100.0 & 100.0 & 100.0 & 100.0 \\
\hline Female partners: & & & & & \\
All my personal income (3) & 7.1 & 0.9 & 7.0 & 3.9 & 0.6 \\
More than half of my personal income (3) & 6.4 & 1.9 & 3.8 & 4.6 & 14.0 \\
About half of my personal income (3) & 8.3 & 1.5 & 2.5 & 4.2 & 16.3 \\
Less than half of my personal income (2) & 11.5 & 14.4 & 14.3 & 44.6 & 26.4 \\
None (1) & 66.7 & 81.3 & 72.4 & 42.7 & 42.6 \\
Total & 100.0 & 100.0 & 100.0 & 100.0 & 100.0 \\
\hline Same answers (\%) & 86.1 & 94.1 & 84.7 & 76.6 & 62.4 \\
\hline
\end{tabular}

Source: EU-SILC 2010 (EU-SILC Cross UDB—version of October 2017). Authors' computations.

Note: Weighted by national cross-sectional weights. Numbers in parenthesis indicate recoding for the purpose of ordered logistic regression. The share of same answers includes only couples where none of partners has missing value.

ners, but mainly by the relative characteristics of these variables between partners - the relative characteristics being our main interest in order to reflect our hypothesis. Marital status, years of cohabitation, and the number of children are also added to the regression analyses as controls.

Budgetary discretion correlates most significantly with couples' total earnings. In all countries, partners located in the higher earnings quintiles are more prone to keep at least half of their resources separate. The strongest relationship is observed in Austria, where the probability that male partners in the top earnings quintile will keep at least half of their income separate is 14 percentage points higher than those in the bottom quintile (see the columns with outcome (3) in Table 3). Complementarily, the probability of their keeping no income separate is 16 percentage points lower for Austrian males (in the top quintile) than for their counterparts in the bottom quintile (see the columns with outcome (1) in Table 3). Similar results are found for female partners (see Table 4). Relative earnings also 


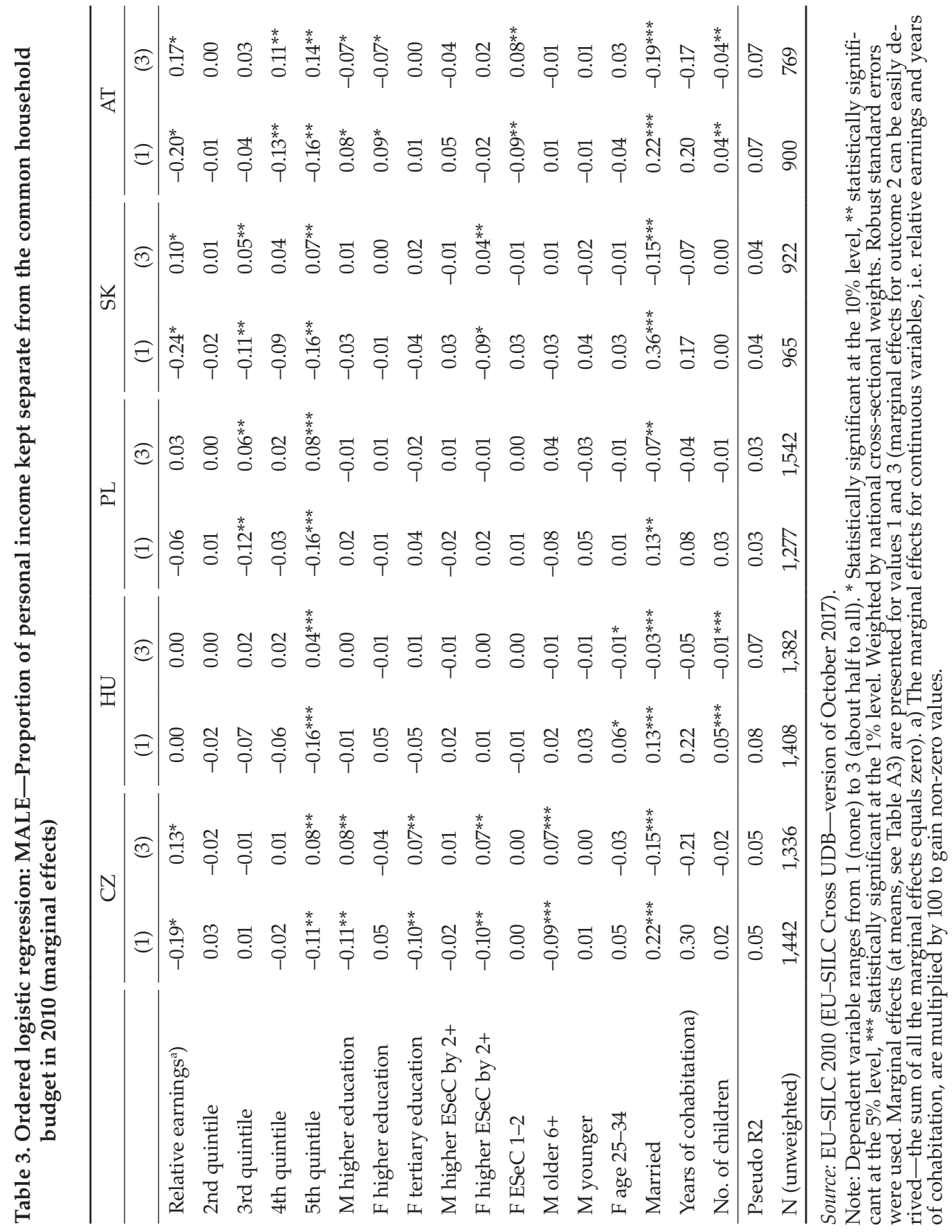




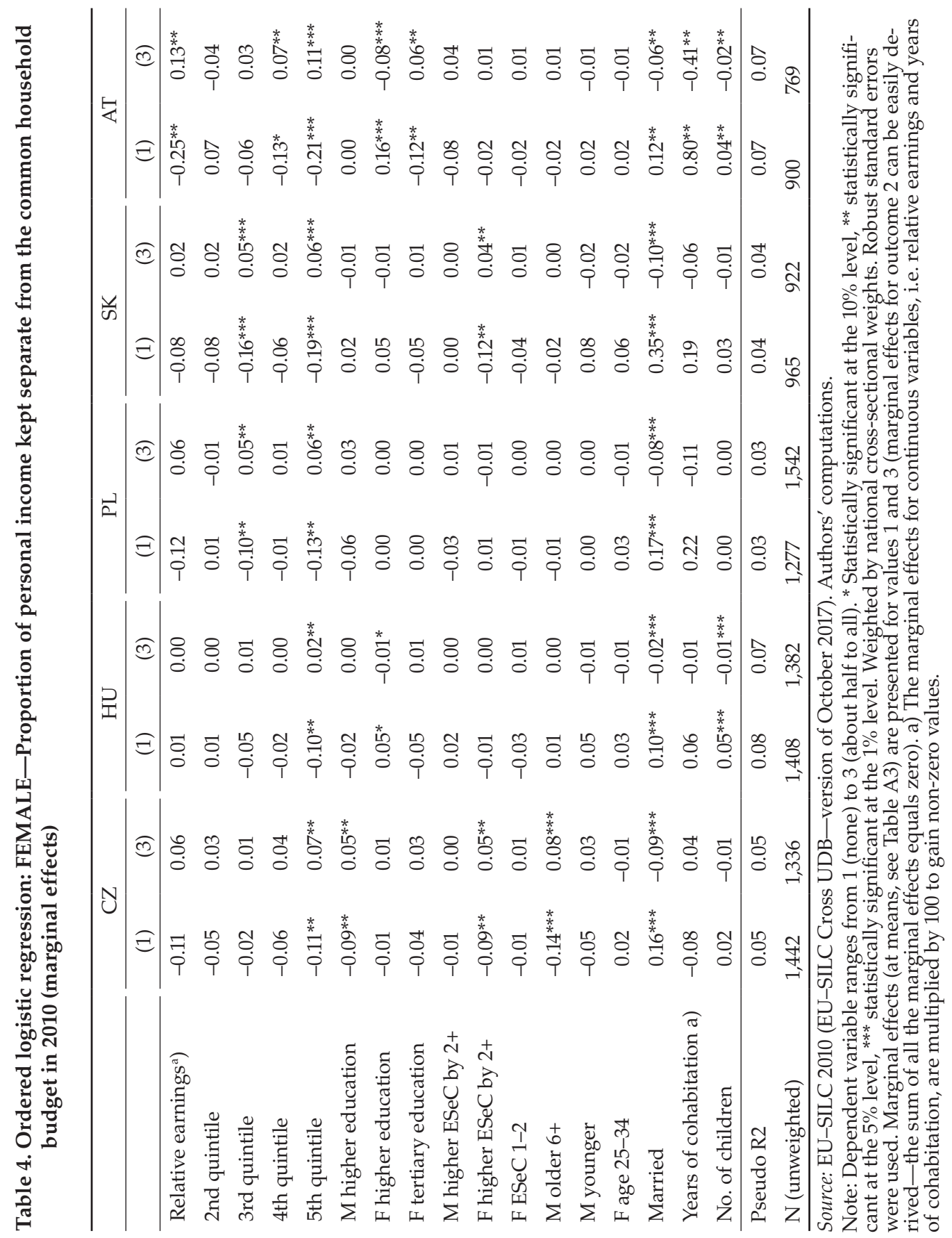


have a positive effect on keeping income separate among Czech men (though in the model without proxy answers the statistical significance is lost; see Table A1 in the Appendix), Slovak men, and both Austrian men and women, meaning that when the relative earnings of women are higher, there is an increased likelihood that (at least of half of) income will be kept separate. ${ }^{9}$ These findings conform to our hypothesis, but not uniformly for all the countries analysed.

Heterogeneity in education level affects budgetary discretion in the Czech Republic, Hungary, and Austria, but in different ways. The results contradict our hypothesis, where we assume that female primacy in education should increase the probability that income will be kept separate. In the Czech Republic, the opposite holds: both male and female partners are more likely to keep a larger share of income separate when the male partner has higher education, compared with educationally homogeneous couples. However, among men the statistical significance of male primacy is lost in the model without proxy answers (see Table A1 in the Appendix), while the positive relationship with female tertiary education remains significant. For women, the results are counterintuitive. Looking more closely at the data (not stated in the tables), we can see that this positive effect of male primacy is only prevalent once women aged $45-54$ are included in the sample: when the model is tested on a subsample of younger women the significance of male educational primacy is lost (the significance and signs of all other coefficients remaining the same).

In Austria, educationally heterogeneous couples are less likely to keep larger shares of income separate; the opposite is true for more educationally homogeneous couples. For male partners (see Table 3), the result of male educational primacy is on the edge of statistical significance and is ultimately lost when we test the results on age subsamples. On the other hand, the relationship between female educational primacy (the factor of our main interest) and budgetary discretion remains negative and significant mainly for the younger and middle cohorts. Therefore, this contradictory finding cannot be explained as an intergenerational difference. The same result contradicting our hypothesis about female educational primacy can be found for Austrian women (see Table 4). Similarly, the negative result is driven by the youngest group of women, aged 25-34. Among Austrian women (especially the youngest age group), only the women's level of education is relevant to the probability that they have budgetary discretion. A similar effect contradicting our hypothesis applies to Hungarian women, who less often keep a larger share of their earnings separate if they have attained a higher level of education than their male counterparts, though with a low level of statistical significance.

\footnotetext{
${ }^{9}$ Note that the marginal effects for relative earnings are multiplied by 100 (see the notes in Tables 3 and 4). For instance, with one percentage point increase in relative earnings, the probability of Austrian men keeping at least half of their income separate increases by 0.17 percentage points.
} 
Relative socio-economic status is significantly associated with separately kept income in the Czech Republic and Slovakia in a similar way, confirming our hypothesis of female primacy. When there is a difference between spouses in favour of the female partner, both partners are more likely to keep a larger share of income separate in the Czech Republic and Slovakia. Relative age has a significant impact only in the Czech Republic, where couples in which the male is six or more years older than the female are more likely to keep a larger share of income separate than couples who are similar in age.

Regarding the effects of the three characteristics relating to female primacy that are of interest to us country by country, some of them are significant in the way we hypothesised in the Czech Republic and Slovakia. One such effect is that the higher the relative (female) earnings, the higher the probability that male partners will keep a larger share of income separate. Also, female primacy in socio-economic status indicates a higher probability that both partners will keep their income separate. Austria confirms our hypothesis in terms of the relative earnings for both partners. On the other hand, female primacy in education contradicts our hypothesis as the results indicate a lower probability of both partners having budgetary discretion. Similarly, in Hungary, higher female education is related to a lower probability of women having budgetary discretion, contradicting our hypothesis, though the statistical significance of this is low. In Poland, none of the female-primacy characteristics affects the probability that a proportion of personal income will be kept separate; only the expected effects of total earnings and marriage-common in all countries-prevail.

Apart from the relative characteristics, marriage is a strong predictor of a lower probability of a larger share of income being kept separate in all countries. Years of cohabitation matter in the same way only for Austrian women. The number of children in the family has similar effects on keeping income separate in Hungary and Austria and decreases the share of income partners keep separate.

\section{Conclusion and discussion}

Social stratification research was dominated for decades by a conventional approach in which the male partner's position determined a family's social status. Similarly, economic research used to look at the household as a single unit based on a traditional division of tasks in the family, where 'male heads' were the primary or sole breadwinners, while wives were primarily occupied with household chores and caring for children. Changing circumstances affecting the position of women in the labour market, the family, and society, resulting in female primacy in relevant characteristics among an increasing proportion of couples, should lead to a re-formulation of this approach. Following the current literature describing changes in the social structure and household economy, this article sought to interlink the two fields of research by revealing the split of partners' 
social status in relation to their separate welfare status, for which budgetary discretion serves as a proxy.

First, we assumed that there is a higher probability that partners will have autonomous social statuses if the woman holds primacy in the relevant personal characteristics. Concretely, we observed couples with status homogeneity/heterogeneity and changes in their composition regarding the three status variables: earnings, education, and socio-economic category. Although the period covered by the 2006-2016 EU-SILC surveys is quite short for detecting such historical changes, some important shifts can be seen: the share of couples in which the woman is superior in at least one aspect has moderately increased in all the countries analysed except Hungary. Taking the percentage of couples with female primacy in two or three aspects as a rough indicator of the 'space' for a possible status split between partners, we saw in 2016 figures (for such couples) ranging between $9 \%$ and $10 \%$ in the Czech Republic and Slovakia and at nearly $15 \%$ in Poland and Austria, with Hungary in the middle at $13 \%$.

Second, using the EU-SILC Module 2010 on well-being, we analysed whether the social status split correlates with a partially independent welfare status of partners in a couple, which is proxied by a substantial proportion of personal income being kept separate from the joint household budget. The three status variables that are assumed to proxy the social status split between partners demonstrated some relevance. But their statistically significant effects are not uniform across countries and are rather scarce. Our hypothesis regarding the link between partners' social status split and their separate welfare status was confirmed for the Czech Republic and Slovakia. In these two countries, female primacy in the socio-economic category and female relative earnings are significantly correlates with the probability of partners' budgetary discretion, though the latter holds for male partners only. In Austria, female relative earnings support our hypothesis even for both partners. Conversely, none of the three factors of social status split correlates significantly with separated welfare status in Hungary and Poland.

Apart from the personal factors of social status split, there are two family factors that are strongly and uniformly related to the probability of budgetary discretion across all countries: household income and marriage. Not surprisingly, a higher household income enables each partner to separate resources from the common budget. This is observed most substantially at the highest household income level (in effect in the fifth income quintile) in CET countries, while this effect is even more pronounced in Austria (in effect from the fourth income quintile). Conversely, marriage (compared to de facto cohabiting) lowers the probability of resources being kept separate, in accordance with the existing empirical findings.

An explanation of the results-suggesting that Poles and Hungarians behave more traditionally, compared to Austria and the two successor countries of former Czechoslovakia - can be sought in two areas. One is the extent of the purchasing power of family budgets, which in essence derives from the country's economic performance. The second-rather broad and mixed area-in which to look for an explanation involves historical roots and values. 
For the first area, which relates to family budgets, there are supportive statistics on economic performance and household income. Between 2006 and 2016, the median equivalised net income of households, corrected by the purchasing power standard, more than doubled in Poland and Slovakia, while it increased by 1.5 times in the Czech Republic and by 1.3 times in Hungary and Austria. In 2010 , the year of our focused analysis, the relative income level was equal to $50 \%$ of the Austrian level of income in the Czech Republic, 34\% in Hungary, 39\% in Poland, and 43\% in Slovakia. Low levels of social/welfare status split in Hungary and Poland thus support the likelihood that tougher financial constraints will have some impact on limiting partners' discretion in household budget management. ${ }^{10}$

On the second area, which relates to specific value orientations, the evidence is scarce and rather vague. This area involves a mixture of historical roots and the recent turmoil of values in the postmodern individualistic society. When searching for country-specific patterns of values, there is not much literature. Using the data of 2008 European Values Study applied to eight European countries (including the Czech Republic and Poland), Grunow, Begall and Buchler [2018] argued for the multidimensional character of gender ideologies by constructing their five profiles. All profiles were found in all countries, but with pronounced variation regarding their size. Striking differences were also observed between the two CET countries, with more gender-egalitarian attitudes in the Czech Republic and more family traditional attitudes in Poland. ${ }^{11}$

In a qualitative study comparing the Czech Republic, Poland, and Hungary, Scharle [2015] observed three fora of public discourse-electoral programmes, parliamentary debates, and media-together with attitudes as measured in surveys. She concluded that ' $(t)$ he pattern of cross country differences seems rather similar across the four areas we examined: gender role attitudes are more traditional in Hungary than in the Czech Republic, and Poland stands somewhere in between' [ibid.: 20].

Questions for future research are how the status split and budgetary discretion in couples will develop and how their relationships will change. Since no such EU-SILC module surveying the intra-household sharing of resources is envisaged by Eurostat for the next several years, we cannot expect comparably solid empirical grounds for comparison across time and countries anytime soon.

${ }^{10}$ See: Mean and Median Income by Household Type-EU-SILC table ilc_di04. At present 2018 data for Slovakia are not available. See: http://appsso.eurostat.ec.europa.eu/nui/ show.do?dataset=ilc_di04\&lang=en.

${ }^{11}$ Let us recall that the term 'gender ideology' (originally coined by the Vatican) is mostly used in a negative sense to refer to a supposedly gay and feminist-led movement to subvert traditional families and social values by expanding protections for sexual and gender minorities, etc. As a reaction, anti-gender discourse and movements have developed across Europe and the world [Kuhar and Paternotte 2018]. See also Davis and Greenstein [2009] for a thorough review of the construction of gender ideology and its consequences. 
When thinking about what possible changes may have occurred since 2010, there are two factors in play that establish the context that-be it indirectly and very hypothetically-affects the phenomenon we are focusing on here. The first is the development of the overall standard of living of households, creating more space for the budgetary discretion of partners in couples. The second is the development of values and ideologies. Two factors may produce effects in opposite directions. While the expansion of family budgets will probably support partners' independence, a possible backsliding towards a more authoritarian and conservative regime might somewhat strengthen traditional family management.

Concerning the first area, and using the same source as above, between 2010 and 2018 the mean equivalised net income per household, corrected by the purchasing power standard, increased by a half in Poland and by about one-third in the other CET countries. The gap between CET countries and Austria thereby decreased in 2010-2018 by ten percentage points in Poland, eight percentage points in the Czech Republic, and six percentage points in Hungary. This was the outcome of favourable years of economic growth during the after-recession period. In the future, in spite of probably generally slower economic growth, the financial situation of households in CET countries will be improving and the gap in family budgets between the East and the West will be closing.

Unlike the first, the second area is much more difficult to forecast. Contrary to the 'end-of-history vision' of development in the direction of strengthening liberal democracy and the arrival of a post-ideological world [Fukuyama 1992], one can instead observe a 'democratic backsliding' [Cianetti, Dawson and Hanley 2018] towards a more authoritarian and conservative regime that reinforces the 'traditional values' of nation, family, and religion. To date these tendencies are more apparent in Hungary and Poland, but they could appear in other countries such as the Czech Republic [Hanley and Vachudova 2018]. Likewise, it is possible to speak of a 'backlash in gender equality', which includes also the area of the economic empowerment of women [European Parliament 2018]. These trends tend to have the effect of altering the value context, which eventually could-indeed very indirectly-limit any further strengthening of social status and welfare independence in couples, generated by larger budgetary discretion.

JIŘí VEČERNÍK is is a senior researcher and head of the Department of Economic Sociology at the Institute of Sociology, Czech Academy of Sciences. His fields of interest are wage and labour market issues, poverty and welfare policies, and social stratification and reporting.

MARTINA Mysíková is a researcher in the Department of Economic Sociology at the Institute of Sociology of the Czech Academy of Sciences. Her fields of specialisation are poverty and well-being, income inequality, and household economics. 


\section{References}

Acker, J. 1973. 'Women and Social Stratification: A Case of Intellectual Sexism.' American Journal of Sociology 78 (4): 936-945, https://doi.org/10.1086/225411.

Blau, P. M. and O. D. Duncan. 1967. The American Occupational Structure. New York: Wiley.

Blossfeld, H.-P. (ed.) 1995. The New Role of Women: Family Formation in Modern Societies. San Francisco, CA, Boulder, CO, and Oxford: Westview Press.

Blossfeld, H.-P. and S. Drobnič. (eds) 2003. Careers of Couples in Contemporary Society: From Male Breadwinner to Dual Earner Families. New York: Oxford University Press.

Blossfeld, H.-P. and S. Buchholz. 2009. 'Increasing Resource Inequality among Families in Modern Societies: The Mechanisms of Growing Educational Homogamy, Changes in the Division of Work in the Family and the Decline of the Male Breadwinner Model.' Journal of Comparative Family Studies 40 (4): 603-616, https://doi.org/10.3138/jcfs.40.4.603.

Bourguignon, F. and P.-A. Chiappori. 1992. ‘Collective Models of Household Behavior: An Introduction.' European Economic Review 36 (2-3): 355-364, https://doi.org/10.1016/0014-2921(92)90091-A.

Carriero, R. and L. Todesco. 2018. 'Housework Division and Gender Ideology: When Do Attitudes Really Matter?' Demographic Research 39 (39): 1039-1064, https://doi.org/10.4054/DemRes.2018.39.39.

Chiappori, P.-A. 1992. 'Collective Labor Supply and Welfare.' Journal of Political Economy 100 (3): 437-467, https://doi.org/10.1086/261825.

Cianetti, L., J. Dawson and S. Hanley. 2018. 'Rethinking “Democratic Backsliding” in Central and Eastern Europe-Looking beyond Hungary and Poland.' East European Politics 34 (3): 243-256, https://doi.org/10.1080/21599165.2018.1491401.

Dale, A., G. N. Gilbert and S. Arber. 1985. 'Integrating Women into Class Theory.' Sociology 19 (3): 384-409, https://doi.org/10.1177/0038038585019003004.

Davis, S. N. and T. N. Greenstein 2009. 'Gender Ideology: Components, Predictors, and Consequences.' Annual Review of Sociology 35 (1): 87-105, https:// doi.org/10.1146/annurev-soc-070308-115920.

Elsas, S. 2016. 'Income Sharing within Households: Evidence from Data on Financial Satisfaction.' Social Sciences 5 (3): 1-16, https://doi.org/10.3390/socsci5030047.

Erikson, R. and J. H. Goldthorpe. 1992. Individual or Family? Results from Two Approaches to Class Assignment.' Acta Sociologica 35 (2): 95-105, https://doi.org/10.1177/000169939203500202.

Esping-Andersen, G. 2009. The Incomplete Revolution: Adapting to Women's New Roles. Cambridge: Polity Press.

European Commission. 2012a. 2010 EU-SILC Module on Intra-Household Sharing of Resources. Assessment of the Implementation. Luxembourg: European Commission, Eurostat.

European Commission. 2012b. The 2010 EU-SILC Module on Intra-Household Sharing of Resources. Research Note 3/2012. Brussels: European Commission. Authors: I. Nagy, M. Medgyesi and O. Lelkes.

European Commission. 2014. Special Eurobarometer 402. Undeclared Work in the European Union. Brussels: DGComm.

European Parliament. 2018. Backlash in Gender Equality and Women's and Girls' Rights. Study requested by the FEMM committee. Authors: B. Juhász, E. Pap (with the assistance of national experts).

Fraboni, R. and A. Vitali. 2019. 'Gender Differences in Couples' Matrimonial Property Regime in Italy.' Journal of Marriage and Family 81 (4): 885-904, https://doi.org/10.1111/jomf.12574. 
Fukuyama, F. 1992. The End of History and the Last Man. Cambridge: The Free Press.

Gardes, F. and C. Starzec. 2009. 'Polish Households' Behavior in the Regular and Informal Economies.' Revue économique 60 (5): 1181-1210, https://doi.org/10.3917/reco.605.1181.

Gauthier, A. H., I. E. Kotowska and D. Vono de Vilhena. (eds) 2018. 'Gender (In)Equality over the Life Course Evidence from the Generations \& Gender Programme.' Population Europe Discussion Paper No. 10. Berlin: Population Europe.

Goldthorpe, J. H. 1983. 'Women and Class Analysis: In Defence of the Conventional View.' Sociology 17 (4): 465-488, https://doi.org/10.1177/0038038583017004001.

Grunow, D., K. Begall and S. Buchler. 2018. 'Gender Ideologies in Europe: A Multidimensional Framework.' Journal of Marriage and Family 80 (1): 42-60, https://doi.org/10.1111/jomf.12453.

Hajdu, G. and T. Hajdu. 2018. 'Intra-couple Income Distribution and Subjective Well-Being: The Moderating Effect of Gender Norms.' European Sociological Review 34 (2): 138-156, https://doi.org/10.1093/esr/jcy006.

Haller, M. 1981. 'Marriage, Women, and Social Stratification: A Theoretical Critique.' American Journal of Sociology 86 (4): 766-795, https:// doi.org/10.1086/227316.

Hamplová, D., C. Le Bourdais and É. Lapierre-Adamcyk. 2014. 'Is the CohabitationMarriage Gap in Money Pooling Universal?' Journal of Marriage and Family 76 (October): 983-997, https://doi.org/10.1111/jomf.12138.

Hanley, S. and M. A. Vachudova. 2018. 'Understanding the Illiberal Turn: Democratic Backsliding in the Czech Republic.' East European Politics 34 (3): 276-296, https://doi.org/10.1080/21599165.2018.1493457.

Harrison, E. and D. Rose. 2006. ESeC User Guide. Colchester: Institute for Social and Economic Research, University of Essex.

Haugh, M. R. 1973. 'Social Class Measurement and Women's Occupation Roles.' Social Forces 52 (1): 86-98, https://doi.org/10.2307/2576426.

Himmelweit, S., C. Santos, A. Sevilla and C. Sofer. 2013. 'Sharing of Resources within the Family and the Economics of Household Decision Making.' Journal of Marriage and Family 75 (3): 625-639, https://doi.org/10.1111/jomf.12032.

Klesment, M. and J. Van Bavel. 2015. 'The Reversal of the Gender Gap in Education and Female Breadwinners in Europe.' Societies-and-Families Working Paper 26. Stockholm: Stockholm University.

Křen, J. 2019. Čtort století střední Evropy: Visegrádské země v globálním př̌́běhu let 1992-2017. (A quarter century of Central Europe. Visegrád countries in the global narrative of 1992-2017) Prague: Karolinum.

Kuhar, R. and D. Paternotte. (eds) 2018. Anti-Gender Campaigns in Europe: Mobilizing against Equality. Lanham: Rowman \& Littlefield.

Kulic, N., A. Minello and S. Zella. 2018. 'Manage Your Money, Be Satisfied? The Role of Income and Money Management Practices in the Financial Well-Being of Swiss Couples.' WP 2018/02. Florence: European University Institute.

Law, H. and J. Sikora 2018. 'Gender Stratification and Feminist Sociology: Why East-Central Europe Needs More Quantitative Gender Stratification Research.' Fabrica Societatis 1 (1): 207-222.

Lucchini, M., C. Saraceno and A. Schizzerotto 2007. 'Dual-Earner and Dual-Career Couples in Contemporary Italy.' Zeitschrift für Familienforschung 19 (3): 289-309.

Lundberg, S. and R. A. Pollak. 1996. 'Bargaining and Distribution in Marriage.' Journal of Economic Perspectives 10: 139-158, https://doi.org/10.1257/jep.10.4.139.

Machonin, P. 1970. 'Social Stratification in Contemporary Czechoslovakia.' American Journal of Sociology 75 (March): 725-741, https://doi.org/10.1086/224818.

Maksymovych, S. 2017. 'Decision-making in the Household and Material Deprivation.' CERGE-EI Working Paper Series No. 604. Prague: CERGE-EI, https://doi.org/10.2139/ssrn.3042788. 
Mann, M. 1986. 'A Crisis in Stratification Theory?' Pp. 40-57 Gender and Stratification, edited by R. Crompton and M. Mann. Cambridge: Polity Press.

Marshall, G., S. Roberts and C. Burgoyne. 1996. 'Social Class and Underclass in Britain and the USA.' British Journal of Sociology 47 (1): 22-67, https://doi.org/10.2307/591114.

Mysíková, M. 2019. 'How Does "the Share of the Pie Matter"? European Empirics on the Financial Satisfaction of Partners.' Ekonomický časopis/Journal of Economics 67: 504-524.

Oakes, J. M. and P. H. Rossi. 2003. 'The Measurement of SES in Health Research: Current Practice and Steps toward a New Approach.' Soc Sci Med 56 (4): 769-784, https://doi.org/10.1016/S0277-9536(02)00073-4.

Oláh, L. Sz., I. E. Kotowska and R. Richter. 2018. 'The New Roles of Men and Women and Implications for Families and Societies.' Pp. 41-64 in A Demographic Perspective on Gender, Family, and Health in Europe, edited by G. Doblhammer and J. Gumà. SpringerOpen, https://doi.org/10.1007/978-3-319-72356-3_4.

Plutzer, E. and J. F. Zipp. 2001. 'Class, Gender, and the Family Unit: A Dynamic Model of Stratification and Class Politics.' Social Science Research 30: 426-448, https://doi.org/10.1006/ssre.2001.0705.

Scharle, Á. 2015. 'Attitudes to Gender Roles in the Czech Republic, Hungary and Poland.' Study produced under grant agreement 'Growth-Innovation-Competitiveness: Fostering Cohesion in Central and Eastern Europe' of the EU FP7/2007-2013.

Schwartz, A. (ed.) 2010. Gender and Modernity in Central Europe: The Austro-Hungarian Monarchy and Its Legacy. Ottawa: University of Ottawa Press.

Sewell, W. H. and R. M. Hauser. 1975. Education, Occupation, and Earnings: Achievement in the Early Career. New York: Academic Press.

Sik, E. 1992. 'From the Second to the Informal Economy.' Journal of Public Policy 12 (2): 153-175, https://doi.org/10.1017/S0143814X00005092.

Sik, E. 2009. 'From the Multicolored to the Black and White Economy. The Hungarian Second Economy and the Transformation.' International Journal of Urban and Regional Research 18 (1): 46-70, https://doi.org/10.1111/j.1468-2427.1994.tb00250.x.

Večerník, J. 2011. 'Self-employment in the Czech Republic and CEE Countries: Persons and Households.' Post-Communist Economies 23 (3): 359-376, https://doi.org/10.1080/14631377.2011.595128.

Vitali, A. and B. Arpino. 2016. 'Who Brings Home the Bacon? The Influence of Context on Partners' Contributions to the Household Income.' Demographic Research 35 (41): 1213-1244, https://doi.org/10.4054/DemRes.2016.35.41.

Vitali, A. and D. Mendola. 2014. 'The Emergence of Women as Main Earners in Europe.' ESRC Centre for Population Change. Working Paper 56, https://doi.org/10.2139/ssrn.2555172.

Ward-Batts, J. 2008. 'Out of the Wallet and into the Purse: Using Micro Data to Test Income Pooling.' Journal of Human Resources 43 (2): 325-351, https://doi.org/10.1353/jhr.2008.0005.

Wesolowski, W. and K. Slomczynski. 1968. 'Social Stratification in Polish Cities.' Pp. 256-274 in Social Stratification, edited by J. A. Jackson. Cambridge: Cambridge University Press.

Wise, R. and C. Zangger. 2017. ‘Educational Homogamy and Inter-Couple Income Inequality: Linking Demographic and Socio-economic Consequences of Educational Expansion in Germany and Switzerland.' Swiss Journal of Sociology 43 (3): 587-610, https://doi.org/10.1515/sjs-2017-0029.

Wright, E. O. 1989. 'Women in the Class Structure.' Politics \& Society 17 (1): 35-66, https://doi.org/10.1177/003232928901700102. 


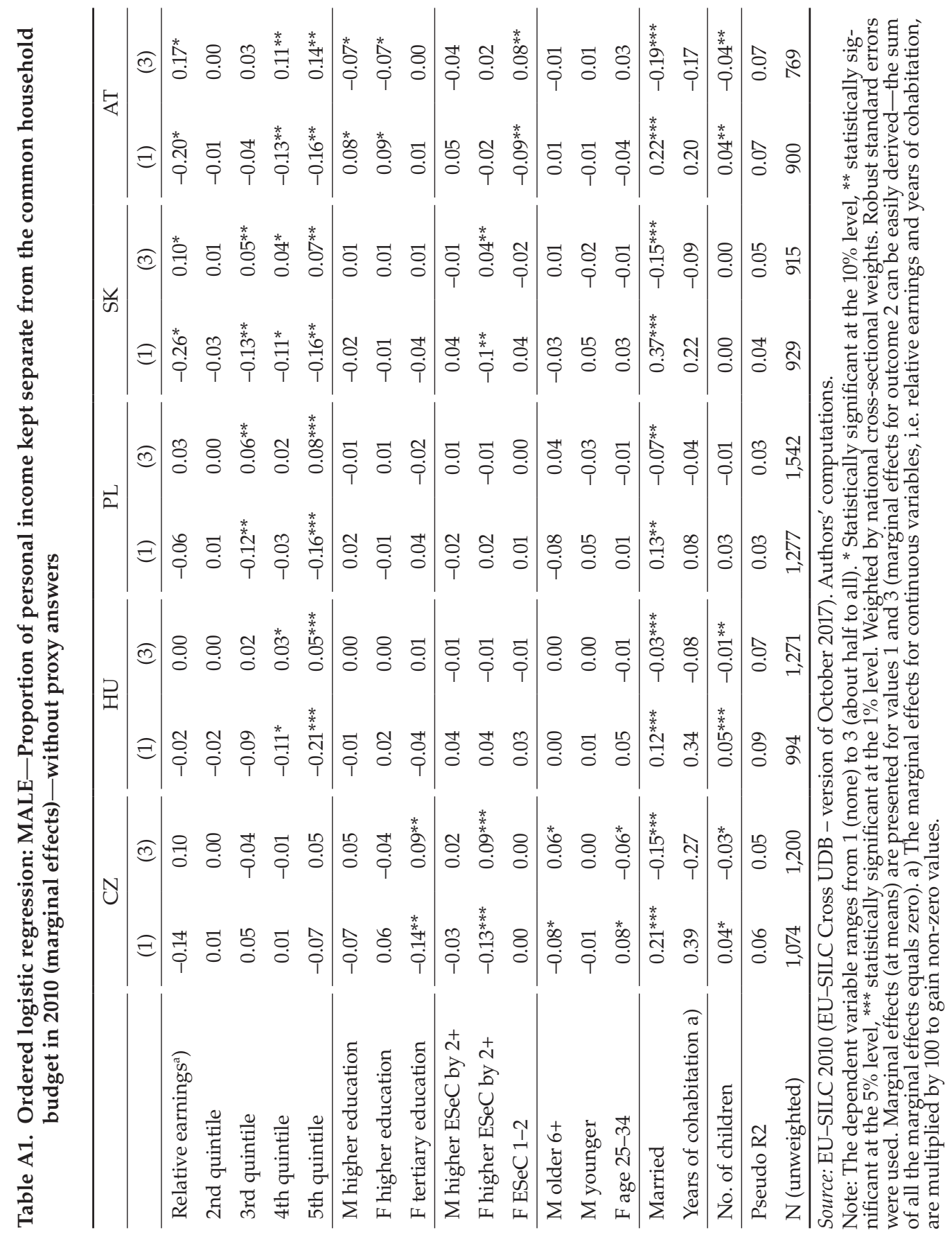




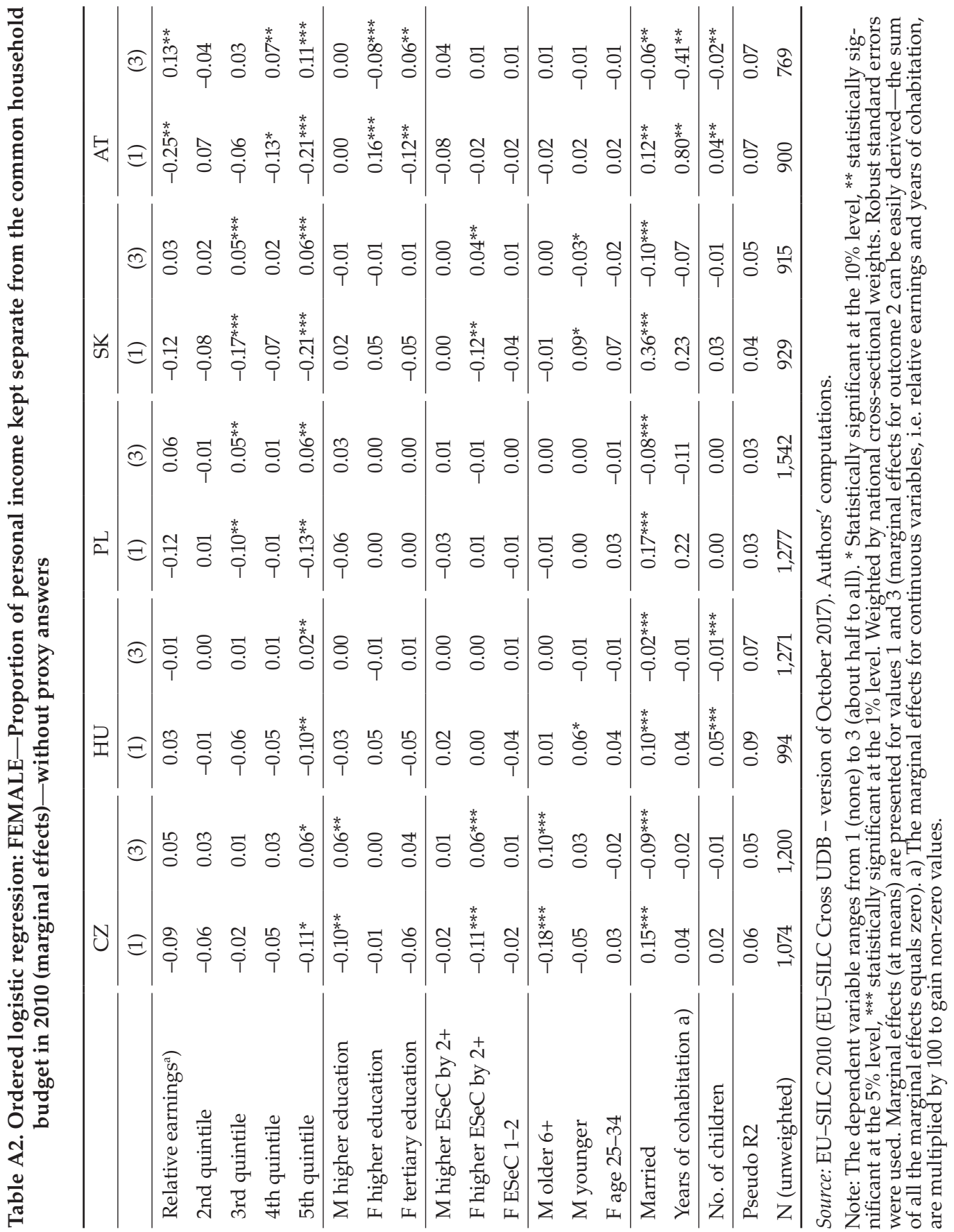




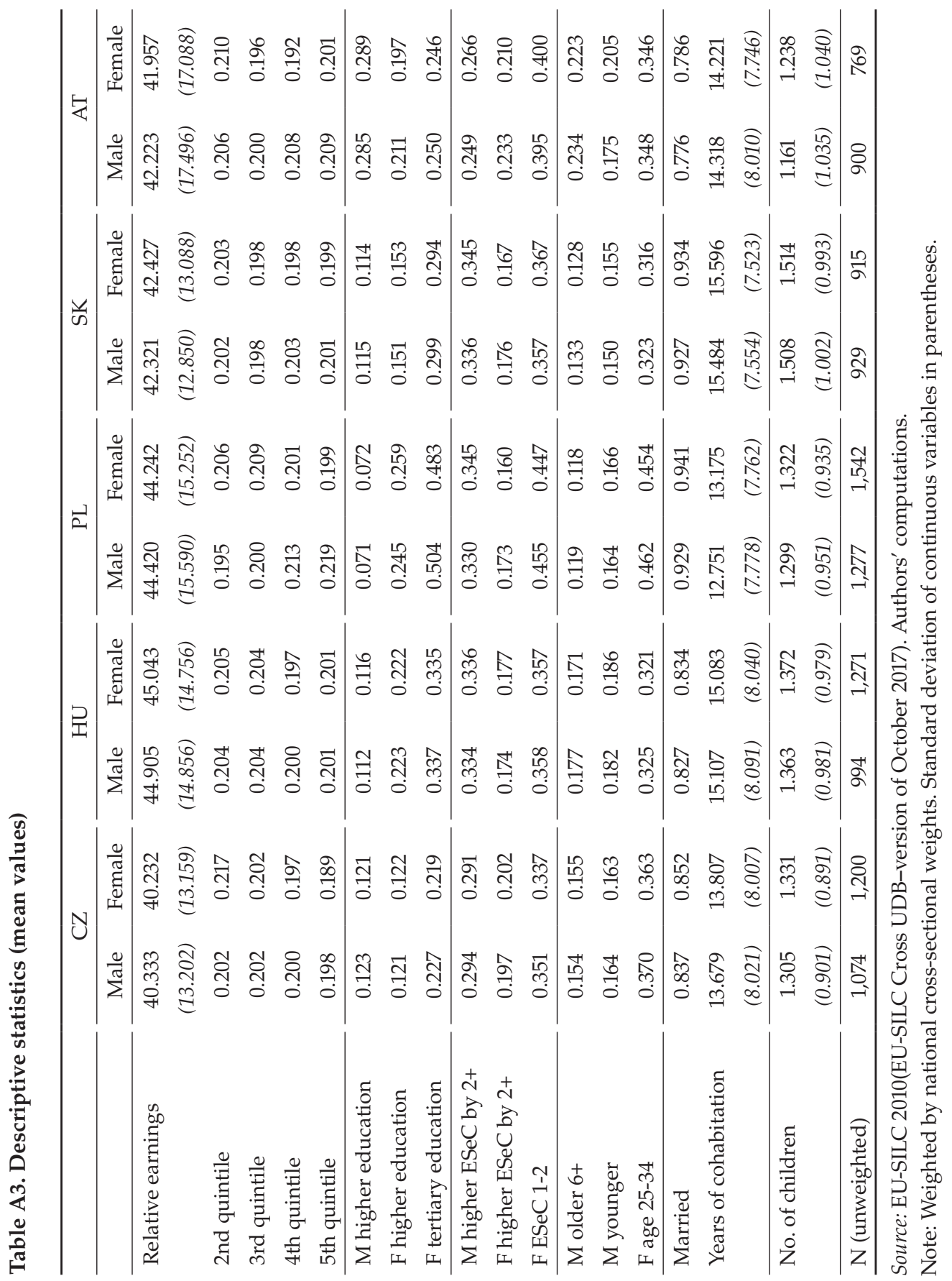

